\title{
An Analysis of the Students' Difficulties in TOEFL Prediction Test of Listening Section
}

\author{
Tira Nur Fitria \\ Institut Teknologi Bisnis AAS Indonesia \\ tiranurfitria@gmail.com
}

\begin{abstract}
This study is to know the students' difficulty in doing the TOEFL prediction test, especially the listening section in ITB AAS Indonesia. This study uses descriptive qualitative research by using a questionnaire. The result shows that the students' difficulty in doing TOEFL listening both external and internal factors. In external factors, include: 1) the speaker's accent (75.5 \%), 2) the speakers' speed (75.9 $\%), 3$ ) the speakers' intonation/emphasis (73\%), 4) the speakers' pause in pronouncing a sentence $(70.3 \%), 5)$ the choice of words and foreign terms conveyed by the speaker $(71 \%), 6)$ the sentence structure conveyed by the speaker is too complex $(54.8 \%), 7)$ audio interruption causes the audio sounds less/unclear (54.8\%). In internal factors, include: 1) $64.3 \%$ of students do not have previous experience doing TOEFL test, 2) $58.5 \%$ of students have lack of practice in TOEFL listening, 3) $78.8 \%$ of students have limited time in doing TOEFL listening test, 4) $62.2 \%$ of students feel a lot of listening questions which consist of 50 questions, 5) $76.2 \%$ of students do not have hearing impairment in listening, 6) $51 \%$ of students have memory limitations when listening to TOEFL, 7) $48.1 \%$ of students lack of motivation and enthusiasm, 8) $52.7 \%$ of students lack of concentration or focus, 9) 53.5 $\%$ of students have limited mastery of foreign/unfamiliar vocabularies, 10) $47.3 \%$ of students feel boredom when listening, 11) $56 \%$ of students feel easily distracted by sounds or other things, 12) $51 \%$ of students tend to translate any foreign vocabularies when listening, 13) $52.7 \%$ of students have trouble catching or finding keywords, 14) 44.4 $\%$ of students are busy along with other activities when listening, such as playing writing instruments, taking notes or doing other things.
\end{abstract}

Keywords: Listening, TOEFL, TOEFL Prediction Test 


\section{INTRODUCTION}

TOEFL stands for Test of English as a Foreign Language. It is a standardized academic English test primarily taken by students applying to universities in the United States. The TOEFL is also accepted as proof of English skill by some universities outside the United States. More than seven thousand colleges and universities in one hundred and thirty countries, including the best universities in the world, such as the U.S., Canada, UK, Australia, and New Zealand. This test is not only used to register at the university but is also required if you want to work in government agencies, take care of licensing, companies, and also for scholarship registration. Setiawan (2013) states that In many nations, TOEFL was used as a criterion for university admission or for obtaining a scholarship. Several Indonesian universities need the TOEFL examination as part of their graduation criteria (Soali \& Pujiani, 2020). TOEFL also becomes one of the standard requirements to enter Indonesian universities (Rahmah, 2019).

TOEFL examines language skills that are tailored to the academic and professional fields. These fields are packaged and divided into sections. TOEFL test usually consists of three sections with 140 questions. TOEFL includes three aspects, namely (1) Listening Comprehension, (2) Structure and Written Expression, (3) Reading Comprehension. The TOEFL test always starts with Listening Comprehension consisting of Part A, B, and C, then followed by Structure and Written Expression consisting of Part A and B, and the last is Reading Comprehension.

Stirling (2017, p. 131) also states that this listening section measures the skill to understand authentic speech patterns used both in academic (formal) and non-academic (informal) situations. Listening Comprehension (50 questions, 30-40 minutes). According to Fitria \& Prastiwi (2020). This section tests how much we can listen to conversations and monologues in English. These conversations consist of short conversations, long conversations, and speeches. Structure and Written Expression (40 questions, 25 minutes).

Listening difficulties include understanding vocabulary, grammar, context, accent or pronunciation, and interesting skill conclusions (Purwaningsih, 2016, p. 2). Some other things that often become problems when facing the TOEFL listening test include not understanding the topic, foreign words, nervousness, being unfamiliar with diction and grammar, repetitions and pauses, wide imagination, 
and missing detailed information, lack of concentration, lack of understanding of English accents, interpret word for word, lack of knowledge of vocabulary and pronunciation, unable to distinguish certain words and sounds. Analyzing students' difficulties toward listening comprehension helped the students in listening test as well as TOEFL test (Darti \& Asmawati, 2017).

The listening comprehension section aims to test our abilities in understanding spoken language. However, to be able to understand spoken language in addition to having to get used to listening to English spoken, we must know English grammar (grammar) adequately. All sentences in this section use the same sentence grammatical (grammatically correct) and usually in the form of a complete sentence. All these sentences are pronounced in conversational English. According to Ang-zie (2020, p. 10), to answer listening comprehension questions well, we are required to have the skill to understand the stress and tone, understand the difference in sound, understand idioms, understand conversational phrases, understanding groups or verb phrases, find implied information (not clearly stated), understand comparisons, and understand the meaning of the conversation or conversation. The listening section is divided into separately timed parts. They are short conversations, long conversations, and talks/monologues. In each part, we will listen to the audio-only one time (Putlack et al., 2020).

Kasmini \& Kadarmo (2014, p. 12) states that all questions in the listening section will usually be played through a headset on the computer or tape using speakers (loudspeakers) that have been prepared for the TOEFL test. Speakers in the tape using American English pronunciations and expressions whose speech and expression are somewhat different from British English (British English). We need to understand the difference especially the way it's pronounced.

Some previous studies were conducted related to TOEFL listening comprehension. In the first research entitled "Investigating Medical Students' Difficulties in TOEFL Listening Test" written by (Rahmi et al., 2020). This research examined the reactions of the students to listening problems in taking the TOEFL test listening portion and their attempts to resolve the difficulties. Most respondents were found to have difficulties recognizing the pronunciation of the native speaker (64\%). As the top rank of students' attempts to solve listening difficulties of the TOEFL exam when viewing English TV programs or movies (65.10 percent) and listening to English songs (60 percent). In the second research entitled "Students Difficulties in Passing Listening Section in TOEFL Prediction Test" written by (Chairuddin \& Ulfa, 2018). 
This research is to recognize difficulties for learners in passing the TOEFL prediction test listening portion. It is found that there are many facets of student issues, and the most difficult items are: 1) capture the idea of the speaker, 2) recognize the idiomatic language, 3) define the coherent marker, 4) give the utterance a literal meaning, 5) retain the important details. The third research entitled "An Analysis of the Difficulties Encountered by Non-English Department Students in TOEFL Test of Listening Section" written by (Pratiwi, 2017). This research was largely aimed at exploring the difficulties of students listening to the TOEFL exam. The outcome of this study reveals that in the listening portion of the TOEFL exam, the recapitulation score of the students was weak, by percentage 60 percent of students include 9 students of fifteen participants are very low understanding, and 40 percent of students include 6 students are low understanding. This suggests that the students are not comfortable with the TOEFL exam. In the fourth research entitled "Analyzing Students' TOEFL Listening Comprehension Test Performance" written by (Yuliandani et al., 2014). The goal of this analysis is to figure out the most challenging part of the TOEFL listening interpretation and to find out the problematic aspects. Double negative expressions (23 percent) are the most problematic aspect, while the most perfected aspect is passive (77 percent). The most troublesome aspect in discussions and talks is the subject matter and accurate knowledge is the mastered aspect. In the fifth research entitled 'Students' Difficulties and Strategies in Doing Listening Section On TOEFL-Like Test" written by (Pujiana, 2015). This analysis is to discover the problems encountered by the students and the approach they used in the TOEFL test listening segment. The effect is that the listening section is not simple for them and that part C (lecture) is the most difficult part of the listening section. The result reveals that students interpret attention, keywords, time, and emphasis as issues. The students usually used some techniques to solve the challenge.

From five previous studies, those have similarities and differences between these studies. Those studies have a similar focus on TOEFL listening comprehension and its difficulties. But there are differences between those previous studies and this study is the objective. Previous studies above focus on the question items related to listening comprehensions such as the pronunciation of the native speaker, the idea of the speaker, idiomatic language, coherent marker, literal meaning, important details, double negative expressions, passive form, attention, keywords, time, and emphasis as issues. It shows only in 
the external factor. While this research focuses on the difficulties in doing the TOEFL listening test based on internal and external factors related to it.

Based on the explanation above, the researcher is interested to research the TOEFL Prediction Test of Reading Comprehension. Finally, the researcher takes the title "The Students' Opinion Toward TOEFL Prediction Test of Reading Comprehension Skill". The researcher formulates the objective of this study is to know the students' difficulty in doing the TOEFL prediction test of listening comprehension skill in ITB AAS Indonesia.

\section{THEORETICAL FRAMEWORK}

In TOEFL, the listening comprehension section is to measure the skill to understand spoken English. It contains listening passages and questions about each passage (Gear \& Gear, 2002, p. 73). Listening questions are divided into 3 parts, namely Part A, Part B, and Part C.

Part A consists of 30 short conversations between two people, each of which will end with one question that you must answer in the correct answer choices (A, B, C, D). This part of Part A consists of 30 questions. Part $\mathrm{B}$ consists of two longer conversations between two people and each conversation is followed by several questions. Generally, the part in Part B consists of seven to eight questions. In part, C consists of 3 long speeches (talks) and only involves one person (monologue). And each speech will be followed by a few questions. Generally for Part C, this consists of seven to eleven questions.

In each of these sections, there will be directions or directions for working on the questions that will be read out by native speakers in audio. The words spoken by native speakers in this direction are almost the same in every TOEFL test. So, it's good if we already know and are familiar with the direction before taking the TOEFL test so that when the direction is being read, we can use this opportunity to read as many answer choices as possible and guess about what questions for the answer choices.

In this section or session, our listening skills will be thoroughly tested. This section is used to test the test participant's ability to listen to a speech or spoken language in English. The participants are expected to be able to listen to every conversation well that comes from a tape recorder or other media. Listening Comprehension on the TOEFL test is always a frightening specter for test-takers, not infrequently many participants fail to pass the test in this session. The time to answer each question in the listening comprehension is very short. We only have no 
more than 8 seconds per problem. For listening questions, it is very important to read all the answer choices.

\section{RESEARCH METHODOLOGY}

This study used descriptive qualitative research. Qualitative research is defined as a study that focuses on understanding in the naturalistic setting or everyday life, or of a certain phenomenon or person (Neergaard \& Ulhøi, 2007, p. 383). They were studies that include the context in which the study's phenomenon is embedded. Taylor et al. (2015, p. 8) stated that qualitative researchers developed concepts, ideas, thoughts, and understanding from patterns in the data rather than collecting data to analyze models, hypotheses, or theories.

The method of collecting data in this study used a questionnaire. Data collection techniques were the most important step in research because the main purpose of the research was to get the data. McNabb (2004, p. 109) stated that a questionnaire could be used to gather information about a large number of respondents (populations) or small groups (samples). In this research, the respondents were fifth-semester students of ITB AAS Indonesia. The researcher uses a closed question. It required the respondent to choose from several predetermined responses (Andrew et al., 2011, p. 82). In this research, the researcher used media for sharing questionnaires by using Google Forms. Google forms provided a simple interface to construct interactive forms that contain a variety of question types (multiple-choice, short answer, long answer, dropdown, etc. (Talbert, 2017). Here, the questions were in the form of multiple-choice with four answer options A, B, C, or D.

In this study, the researcher used the technique of data analysis based on Miles and Huberman (1994) which is involving three steps: data reduction, data display, and conclusion drawing/verification. The results of questionnaire data processing were often presented in descriptive form.

\section{FINDINGS AND DISCUSSION FINDINGS}

The objective of this study is to know the students' difficulty in doing the TOEFL prediction test of listening comprehension skills. Two factors cause the students are difficulty in doing TOEFL listening in both external and internal factors. Below the findings of the research as follow: 
Tira Nur Fitria: An Analysis of the Students' Difficulties of TOEFL Prediction Test of Listening Section $\mid 101$

Table 1.

External Factor

\begin{tabular}{|c|c|c|c|}
\hline \multirow[t]{2}{*}{ STATEMENT } & \multicolumn{3}{|c|}{ Indicator } \\
\hline & Yes & Sometimes & No \\
\hline $\begin{array}{l}\text { 1. The speaker's accent affects } \\
\text { your TOEFL Listening skill. }\end{array}$ & $\begin{array}{l}182 \\
(75.5 \%)\end{array}$ & $56(23.2 \%)$ & $3(1.2 \%)$ \\
\hline $\begin{array}{l}\text { 2. Speakers' speed affects your } \\
\text { TOEFL Listening skill. }\end{array}$ & $\begin{array}{l}183 \\
(75.9 \%)\end{array}$ & $52(21.6 \%)$ & $6(2.5 \%)$ \\
\hline $\begin{array}{l}\text { 3. Speakers' intonation/emphasis } \\
\text { affects your TOEFL Listening } \\
\text { skill. }\end{array}$ & $\begin{array}{l}176 \\
(73 \%)\end{array}$ & $59(24.5 \%)$ & $6(2.5 \%)$ \\
\hline $\begin{array}{l}\text { 4. The speakers' pause in } \\
\text { pronouncing a sentence affects } \\
\text { your TOEFL Listening skill. }\end{array}$ & $\begin{array}{l}144 \\
(59.8 \%)\end{array}$ & $73(70.3 \%)$ & $24(10 \%)$ \\
\hline $\begin{array}{l}\text { 5. The choice of words (diction) } \\
\text { and foreign terms conveyed by } \\
\text { the speaker affects your TOEFL } \\
\text { listening skill. }\end{array}$ & $\begin{array}{l}171 \\
(71 \%)\end{array}$ & $60(24.9 \%)$ & $10(4.1 \%)$ \\
\hline $\begin{array}{l}\text { 6. The sentence structure } \\
\text { conveyed by the speaker is too } \\
\text { complex so it affects your } \\
\text { TOEFL Listening skill. }\end{array}$ & $\begin{array}{l}132 \\
(54.8 \%)\end{array}$ & $95(39.4 \%)$ & $14(5.8 \%)$ \\
\hline $\begin{array}{l}\text { 7. Audio interruption makes the } \\
\text { audio sounds less/unclear } \\
\text { when you are Listening TOEFL. }\end{array}$ & $\begin{array}{l}132 \\
(54.8 \%)\end{array}$ & $72(29.99 \%)$ & $\begin{array}{l}37 \\
(15.4 \%)\end{array}$ \\
\hline
\end{tabular}

Form the table above shows that several external factors caused difficulty in doing the TOEFL prediction test of listening comprehension. The first statement about "The speaker's accent affects your TOEFL Listening skill". There are 182 students or $75.5 \%$ who said 'yes, 56 students or $23.2 \%$ said 'sometimes, and only 3 students or $1.2 \%$ said 'no'. Based on those answers, it shows that most students feel that the speaker's accent affects their TOEFL Listening skill". The second statement about "Speakers' speed affects your TOEFL Listening skill". There are 183 students or $75.9 \%$ who said 'yes, 52 students or $21.6 \%$ said 'sometimes, and only 6 students or $2.5 \%$ said 'no'. Based on those answers, it shows that most students feel that the speakers' speed affects their TOEFL Listening skills. The third statement about "Speakers' intonation/emphasis affects your TOEFL Listening skill". There are 176 students or $73 \%$ who said 'yes, 59 students or $24.5 \%$ 
said 'sometimes, and only 6 students or $2.5 \%$ said 'no'. Based on those answers, it shows that most students feel that the speakers' intonation/emphasis affects their TOEFL Listening skills. The fourth statement about "Speakers' pause in pronouncing a sentence affects your TOEFL Listening skill". There are 144 students or $59.8 \%$ who said 'yes' 73 students or $70.3 \%$ said sometimes only 24 students or $10 \%$ said 'no'. Based on those answers, it shows that most students feel that the speakers' pause in pronouncing a sentence affects their TOEFL Listening skills. The fifth statement about "The choice of words (diction) and foreign terms conveyed by the speaker affects your TOEFL listening skill". There are 171 students or $71 \%$ said yes, 60 students or $24.9 \%$ said 'sometimes only 10 students or $4.1 \%$ said 'no'. Based on those answers, it shows that most students feel that the choice of words (diction) and foreign terms conveyed by the speaker affects their TOEFL listening skills. The sixth statement about "The sentence structure conveyed by the speaker is too complex then affects your TOEFL Listening skill". There are 132 students or $54.8 \%$ who said 'yes', 95 students, or $39.4 \%$ said 'sometimes only 14 students or $5.8 \%$ said 'no'. Based on those answers, it shows that most students feel that the sentence structure conveyed by the speaker is too complex then affects their TOEFL Listening skills. The seventh statement about "There is audio interruption so that the audio sounds less/unclear in Listening TOEFL." There are 132 students or $54.8 \%$ said 'yes', 72 students or 29.8 $\%$ said 'sometimes', and 37 students or $15.4 \%$ said 'no'. Based on those answers, it shows that most students feel that audio interruption makes the audio sounds less/unclear in Listening TOEFL".

Table 2.

Internal Factor (1)

\begin{tabular}{|c|c|c|c|}
\hline \multirow[t]{2}{*}{ STATEMENT } & \multicolumn{3}{|c|}{ Indicator } \\
\hline & Yes & & No \\
\hline $\begin{array}{l}\text { 1. Having previous experience doing } \\
\text { TOEFL test before }\end{array}$ & $86(35.7 \%)$ & 155 & $(64.3 \%)$ \\
\hline $\begin{array}{l}\text { 2. Lack of practice in listening to } \\
\text { TOEFL }\end{array}$ & $100(41.5 \%)$ & 141 & $(58.5 \%)$ \\
\hline $\begin{array}{l}\text { 3. Limited time in doing TOEFL } \\
\text { listening test }\end{array}$ & $190(78.8 \%)$ & 511 & $1.2 \%)$ \\
\hline
\end{tabular}


Form the table above shows that some internal factors caused difficulty in doing the TOEFL prediction test of the listening section. The $1^{\text {st }}$ statement about "Have previous experience in doing TOEFL test before". There are 86 students or $35.7 \%$ who said 'yes' and 155 students or $64.3 \%$ said 'no'. Based on those answers, it shows that most students do not have previous experience in listening to the TOEFL. The $2^{\text {nd }}$ statement about "Lack of practice in listening to TOEFL". There are 100 students or $41.5 \%$ who said 'yes' and 141 students or $58.5 \%$ said 'no'. Based on those answers, it shows that most students do not lack practice in listening to TOEFL before. The $3^{\text {rd }}$ statement about "Limited time in doing TOEFL listening test". There are 190 students or $78.8 \%$ who said 'yes' and 51 students or $21.2 \%$ said 'no'. Based on those answers, it shows that most students have limited time in doing the TOEFL listening test.

Table 3.

Internal Factor (2)

\begin{tabular}{clll}
\hline \multirow{2}{*}{ STATEMENT } & \multicolumn{3}{c}{ Indicator } \\
\cline { 2 - 4 } & \multicolumn{1}{c}{ Many } & Enough & Less \\
\hline 4. A lot of listening questions which & 150 & 90 & 0 \\
consist of 50 questions & $(62.2 \%)$ & $(37.3 \%)$ & $(0 \%)$ \\
\hline
\end{tabular}

The $4^{\text {th }}$ statement about "A lot of listening questions which consist of 50 questions". There are 150 students or $62.2 \%$ who said 'many', 90 students or $37.3 \%$ said 'enough', and 51 students or $21.2 \%$ said 'less'. Based on those answers, it shows that most students feel that many listening questions because it consists of 50 questions.

Table 4.

Internal Factor (3)

\begin{tabular}{|c|c|c|c|}
\hline \multirow[t]{2}{*}{ STATEMENT } & \multicolumn{3}{|c|}{ Indicator } \\
\hline & Yes & Sometimes & No \\
\hline $\begin{array}{l}\text { 5. Have hearing impairment in } \\
\text { listening to TOEFL }\end{array}$ & $\begin{array}{l}45 \\
(18.7 \%)\end{array}$ & $\begin{array}{l}31 \\
(12.9 \%)\end{array}$ & $\begin{array}{l}162 \\
(76.2 \%)\end{array}$ \\
\hline $\begin{array}{l}\text { 6. Have memory limitations } \\
\text { when listening to the TOEFL }\end{array}$ & $\begin{array}{l}123 \\
(51 \%)\end{array}$ & $\begin{array}{l}87 \\
(36.1 \%)\end{array}$ & $\begin{array}{l}31 \\
(12.9 \%)\end{array}$ \\
\hline $\begin{array}{l}\text { 7. Lack of motivation and } \\
\text { enthusiasm when listening to }\end{array}$ & $\begin{array}{l}51 \\
(21.2 \%)\end{array}$ & $\begin{array}{l}116 \\
(48.1 \%)\end{array}$ & $\begin{array}{l}74 \\
(30.7 \%)\end{array}$ \\
\hline
\end{tabular}




\begin{tabular}{|c|c|c|c|}
\hline DEFL & & & \\
\hline $\begin{array}{l}\text { 8. Lack of concentration/focus } \\
\text { when listening to TOEFL }\end{array}$ & $82(34 \%)$ & $\begin{array}{l}127 \\
(52.7 \%)\end{array}$ & $\begin{array}{l}32 \\
(13.3 \%)\end{array}$ \\
\hline $\begin{array}{l}\text { 9. Have limited mastery of } \\
\text { foreign / unfamiliar } \\
\text { vocabulary when listening }\end{array}$ & $\begin{array}{l}129 \\
(53.5 \%)\end{array}$ & $\begin{array}{l}103 \\
(42.7 \%)\end{array}$ & $\begin{array}{l}9 \\
(3.7 \%)\end{array}$ \\
\hline $\begin{array}{l}\text { 10. The appearance of boredom } \\
\text { when listening to TOEFL }\end{array}$ & $\begin{array}{l}100 \\
(41.5 \%)\end{array}$ & $\begin{array}{l}114 \\
(47.35)\end{array}$ & $\begin{array}{l}27 \\
(11.2 \%)\end{array}$ \\
\hline $\begin{array}{l}\text { 11. Easily distracted by sounds or } \\
\text { other things when listening to } \\
\text { TOEFL }\end{array}$ & $\begin{array}{l}135 \\
(56 \%)\end{array}$ & $\begin{array}{l}89 \\
(36.9 \%)\end{array}$ & $17(7.1 \%)$ \\
\hline $\begin{array}{l}\text { 12. Tend to interpret any foreign } \\
\text { vocabulary when listening to } \\
\text { TOEFL }\end{array}$ & $\begin{array}{l}123 \\
(51 \%)\end{array}$ & $\begin{array}{l}105 \\
(43.6 \%)\end{array}$ & $13(5.4 \%)$ \\
\hline $\begin{array}{l}\text { 13. Have trouble catching or } \\
\text { finding keywords when } \\
\text { listening to TOEFL }\end{array}$ & $\begin{array}{l}108 \\
(44.8 \%)\end{array}$ & $\begin{array}{l}127 \\
(52.7 \%)\end{array}$ & $6(2.5 \%)$ \\
\hline $\begin{array}{l}\text { 14. Busy alone with other } \\
\text { activities when listening to } \\
\text { TOEFL, for example playing } \\
\text { writing instruments, taking } \\
\text { notes, or doing other things. }\end{array}$ & $\begin{array}{l}38 \\
(15.8 \%)\end{array}$ & $\begin{array}{l}107 \\
(44.4 \%)\end{array}$ & $\begin{array}{l}96 \\
(39.8 \%)\end{array}$ \\
\hline
\end{tabular}

The $5^{\text {th }}$ statement about "Have hearing impairment in listening to TOEFL". There are 45 students or $18.7 \%$ who said 'yes', 31 students or $12.9 \%$ said 'sometimes' and 162 students or $76.2 \%$ said 'no'. Based on those answers, it shows that most students do not have hearing impairment in listening to TOEFL. The $6^{\text {th }}$ statement about "Have memory limitations when listening to TOEFL". There are 123 students or $51 \%$ who said 'yes', 87 students or $36.1 \%$ said 'sometimes' and 31 students or $12.9 \%$ said 'no'. Based on those answers, it shows that most students feel that they have memory limitations when listening to TOEFL. The $7^{\text {th }}$ statement about "Lack of motivation and enthusiasm when listening to TOEFL". There are 51 students or $21.2 \%$ who said 'yes', 116 students, or $48.1 \%$ said 'sometimes' and 74 students, or 30.7 $\%$ said 'no'. Based on those answers, it shows that most students sometimes feel a lack of motivation and enthusiasm when listening to TOEFL. The $8^{\text {th }}$ statement about "Lack of concentration or focus when listening to TOEFL". There are 82 students or $34 \%$ who said 'yes', 127 
students or $52.7 \%$ said 'sometimes' and 32 students or $13.3 \%$ said 'no'. Based on those answers, it shows that most students sometimes feel a lack of concentration or focus when listening to TOEFL. The $9^{\text {th }}$ statement about "Have a limited mastery of foreign or unfamiliar vocabulary when listening to TOEFL". There are 129 students or $53.5 \%$ who said 'yes', 103 students or $42.7 \%$ said 'sometimes' and 9 students or $3.7 \%$ said 'no'. Based on those answers, it shows that most students feel to have limited mastery of foreign or unfamiliar vocabulary when listening to TOEFL. The $10^{\text {th }}$ statement about "The appearance of boredom when listening to TOEFL". There are 100 students or $41.5 \%$ who said 'yes', 114 students or $47.3 \%$ said 'sometimes' and 27 students or $11.2 \%$ said 'no'. Based on those answers, it shows that most students have boredom when listening to TOEFL. The $11^{\text {th }}$ statement about "Easily distracted by sounds or other things when listening to TOEFL". There are 135 students or $56 \%$ who said 'yes', 89 students or $36.9 \%$ said 'sometimes' and 17 students or $7.1 \%$ said 'no'. Based on those answers, it shows that most students feel that they are easily distracted by sounds or other things when listening to TOEFL". The $12^{\text {th }}$ statement about "Tend to interpret any foreign vocabulary when listening to TOEFL". There are 123 students or $51 \%$ who said 'yes', 105 students or $43.6 \%$ said 'sometimes' and 13 students or $5.4 \%$ said 'no'. Based on those answers, it shows that most students tend to interpret any foreign vocabulary when listening to TOEFL. The $13^{\text {th }}$ statement about "Have trouble catching or finding keywords when listening to TOEFL". There are 108 students or $44.8 \%$ who said 'yes', 127 students, or $52.7 \%$ said 'sometimes' and only 6 students, or $2.5 \%$ said 'no'. Based on those answers, it shows that most students sometimes have trouble catching or finding keywords when listening to TOEFL. The $14^{\text {th }}$ statement about "Busy alone with other activities when listening to TOEFL, for example playing writing instruments, taking notes or doing other things". There are 38 students or $15.8 \%$ who said 'yes', 107 students or $44.4 \%$ said 'sometimes' and 96 students or $39.8 \%$ said 'no'. Based on those answers, it shows that most students sometimes busy along with other activities when listening to TOEFL, for example playing writing instruments, taking notes, or doing other things.

\section{DISCUSSION}

The first session of the TOEFL test is a listening comprehension test (Listening Comprehension). This listening session generally consists of 50 questions. The students/learners will hear the recording in English 
and we have to respond or answer questions related to the recording. The students/learners have to listen to the recording as much as possible because The students/learners will only hear the recording once and the recorded material is not written in the test book. There are three sessions in this listening test: PART A which consists of 30 short conversations, each conversation is followed by several questions, PART $\mathrm{B}$ which consists of 2 long conversations followed by several questions, and PART $\mathrm{C}$ which consists of 3 talks/lectures (like a lecturer explaining a certain topic).

In the TOEFL test, The students/learners will meet several question sessions. One of them is a listening session. In this session, The students/learners will hear English native speakers talk, have dialogues, or even listen to short speeches or short speeches. After listening to the audio, we must answer the questions related to the audio earlier. In dealing with this listening question, several strategies are needed in doing the listening test. The listening Comprehension Section aims to test the skill to understand spoken language. However, to be able to understand the spoken language, besides having to get used to listening to spoken English, we must have a knowledge of the structure of adequate English (grammar). All sentences in this section use a grammatically correct sentence (correct according to grammar) and usually in the form of a complete sentence (Purnaning et al., 2014, p. 10). All these sentences are pronounced in conversational English.

Listening is the most difficult part of the TOEFL test for most people. For many people listen is the most difficult language skill (Sudarmono, 2018, p. 35). According to Marwan (2020), Students experience three categories of difficulties: those related to the subject, those related to the listener, and those related to the physical environment. For the structure section and reading we can anticipate by understanding grammar material and master a lot of basic vocabulary, then practice the TOEFL test. Difficulty in doing TOEFL listening questions is a fairly complex activity, meaning that there are many aspects and many factors that influence it. These factors are interrelated, in other words, that reading difficulty is influenced by one another. Students need to implement more strategies, and teachers or educators are recommended to inspire them and develop their awareness to use more strategies when taking a TOEFL (Razmalia \& Gani, 2017).

Two factors cause the students are difficulty in doing TOEFL listening in both external and internal factors. In external factors, they are: 1) The speaker's accent affects your TOEFL Listening skill. 2) 
Speakers' speed affects your TOEFL Listening skill. 3) Speakers' intonation/emphasis affects your TOEFL Listening skill. 4) The speakers' pause in pronouncing a sentence affects your TOEFL Listening skill. 5) The choice of words (diction) and foreign terms conveyed by the speaker affects your TOEFL listening skill. 6) The sentence structure conveyed by the speaker is too complex so it affects the TOEFL Listening skill. 7) Audio interruption makes the audio sounds less/unclear when Listening TOEFL.

In internal factors, they are: 1) Do not have previous experience doing TOEFL test before. 2) Have a lack of practice in listening to TOEFL. 3) Have limited time in doing the TOEFL listening test. 4) A lot of listening questions which consist of 50 questions. 5) Have hearing impairment in listening to TOEFL. 6) Have memory limitations when listening to TOEFL. 7) Lack of motivation and enthusiasm when listening to TOEFL. 8) Lack of concentration or focus when listening to TOEFL. 9) Have limited mastery of foreign or unfamiliar vocabulary when listening. 10) The appearance of boredom when listening to TOEFL. 11) Easily distracted by sounds or other things when listening to TOEFL. 12) Tend to translate any foreign vocabulary when listening to TOEFL. 13) Have trouble catching or finding keywords when listening to TOEFL. 14) Busy alone with other activities when listening to TOEFL, for example playing writing instruments, taking notes, or doing other things.

There are a variety of instructor techniques for teaching TOEFL Listening Preparation (Khobir \& Qonaatun, 2020). First, teacher strategies will help students become more confident speakers and listeners. Second, instructor tactics will help students feel more at ease when taking the TOEFL test. Third, the student's ability to understand native speakers can be improved by listening to them often. Fourth, the student should take a more involved role in taking the TOEFL. Finally, the student understands how to answer type questions on the TOEFL, especially in the listening section of the strategies.

\section{CONCLUSION}

TOEFL Listening section is arguably a little more difficult than the other section. It is not surprising that many people find it difficult to improve their English Listening skills. Unlike the other TOEFL sections, listening skills cannot be improved in just a short time. It takes stages and processes that are gradual until someone can sort out the words that are heard well. Listening is the most difficult part of the TOEFL test in most people's view. For the structure section and reading, the students/learners can anticipate by understanding grammar material 
and master a lot of basic vocabulary, then practice a lot do the TOEFL standard questions. Difficulty in doing TOEFL listening questions is a fairly complex activity, meaning that there are many aspects and many factors that influence it both external or internal. Internal factors include the listener's physical condition and the listener's psychological condition. The physical condition of a listener is an important factor that determines the success and quality of listening. These factors are interrelated, in other words, that reading difficulty is influenced by one another. External factors include environmental conditions (physical environment and social environment). Environmental factors have a big influence on the success of the listening process. Environmental factors in the form of the physical environment and social environment. As good listeners, The students/learners should know and understand what factors influence the listening process and try to minimize them, so that listening can run smoothly and optimally. Listening is an important activity in everyday life, not only in school but wherever we are. Be a good listener so that we can increase our knowledge and knowledge, and strengthen the brotherly relationship between humans, because one of the objectives of listening is to communicate and to get information.

\section{REFERENCES}

Andrew, D. P. S., Pedersen, P. M., \& McEvoy, C. D. (2011). Research Methods and Design in Sport Management. Human Kinetics.

Ang-zie, M. K. (2020). 14 Exams In Preparation \& Practice Test Toefl: Toefl. Genta Group Production.

Chairuddin, C., \& Ulfa, M. (2018). Students Difficulties in Passing Listening Section in TOEFL Prediction Test. SEUNEUBOK LADA: Jurnal Ilmu-Ilmu Sejarah, Sosial, Budaya Dan Kependidikan, 5(1), 16-27.

https://ejurnalunsam.id/index.php/jsnbl/article/view/628

Dakhi, S., \& Fitria, T. N. (2019). The principles and the teaching of English vocabulary: A review. Journal of English teaching, 5(1).

Darti, \& Asmawati, A. (2017). Analyzing Students' Difficulties Toward Listening Comprehension. ETERNAL (English, Teaching, Learning and Research Journal), 3(2), 206-220. https://doi.org/10.24252/Eternal.V32.2017.A9

Fitria, T. N., \& Prastiwi, I. E. (2020). Pelatihan Tes Toefl (Test of English Foreign Language) Untuk Siswa SMK/SMA, Mahasiswa, Dosen 
dan Umum. BUDIMAS : JURNAL PENGABDIAN MASYARAKAT, 2(2), Article 2. https://doi.org/10.29040/budimas.v2i2.1457

Fitria, T. N. (2020). Teaching English through Online Learning System during Covid-19 Pandemic. Pedagogy: Journal of English Language Teaching, 8(2), 138-148.

Fitria, T. N. (2021). Implementation of Institution's E-Learning Platform in Teaching Online at ITB AAS Indonesia. EDUTEC: Journal of Education And Technology, 4(3), 493-503.

Fitria, Tira Nur. "An Analysis of Regular and Irregular Verbs in Students' Essay Writing." LLT Journal: A Journal on Language and Language Teaching 24, no. 1 (April 9, 2021): 276-87. https://doi.org/10.24071/llt.v24i1.2595.

Gear, J., \& Gear, R. (2002). Cambridge Preparation for the TOEFL® Test Book with CD-ROM. Cambridge University Press.

Kasmini, M., \& Kadarmo, S. (2014). 99\% Sukses Menghadapi TOEFL: Metode Terbaik melejitkan Skor TOEFL. Cmedia.

Khobir, W. A., \& Qonaatun, A. (2020). English Teacher' Strategy In Teaching Listening Section of TOEFL Preparations. Journal of English Language Teaching and Literature (JELTL), 3(2), 127-135. https://doi.org/10.47080/jeltl.v3i2.995

Marwan. (2020). An Analysis of the Difficulties Encountered by English Department Students In Listening Section of TOEFL Test [PeerReviewed]. IAIN SALATIGA. http://erepository.perpus.iainsalatiga.ac.id/9894/

McNabb, D. E. (2004). Research Methods for Political Science. M.E. Sharpe.

Neergaard, H., \& Ulhøi, J. P. (2007). Handbook of Qualitative Research Methods in Entrepreneurship. Edward Elgar Publishing.

Pratiwi, L. (2017). An Analysis of the Difficulties Encountered by NonEnglish Department Students in TOEFL Test of Listening Section ( $A$ Case Study at Arabic Education Department IAIN SMH Banten) [Diploma, Uin Sultan Maulana Hasanudin Banten]. http://repository.uinbanten.ac.id/649/

Pujiana, M. (2015). Students' Difficulties and Strategies in Doing Listening Section On TOEFL-Like Test: A Case Study at the Eighth Semester Students of FKIP Mataram University [Skripsi, Universitas Mataram]. http://eprints.unram.ac.id/2523/

Purnaning, E. R., Ayuningtyas, A. K., Kridaningtyas, I., \& Hudha, N. (2014). Upgrade TOEFL Score: Rahasia Melejitkan Skor TOEFL. Cmedia. 
Purwaningsih, Y. S. (2016). TOEFL ASYIK: (Chapter 1: LISTENING COMPREHENSION). IndonesiaTera.

Putlack, M. A., Poirier, S., \& Tolochko, M. (2020). Decoding the TOEFL® iBT Actual Test LISTENING 2 (New TOEFL Edition). Darakwon.

Rahmah, 140203061. (2019). The Students' Problems In Listening Comprehension of TOEFL Test [Skripsi, Fakultas Tarbiyah dan Keguruan UIN Ar-Raniry Banda Aceh]. http://library.arraniry.ac.id/

Rahmi, F. A., Kasim, U., \& Aziz, Z. A. (2020). Investigating Medical Students' Difficulties in TOEFL Listening Test. 16.

Razmalia, A., \& Gani, S. A. (2017). Students' Strategies in Taking TOEFL Listening Test. Research in English and Education Journal, 2(4), 19. http://jim.unsyiah.ac.id/READ/article/view/7172

Setiawan, A. (2013). A Study on Difficulties of Listening Comprehension of TOEFL at State Islamic College of Jurai Siwo Metro [Undergraduate, IAIN Metro]. https://repository.metrouniv.ac.id/id/eprint/3052/

Soali, M., \& Pujiani, T. (2020). An Error Analysis of Non- English Students Department in Answering Listening Section in TOEFL. J-LEE Journal of Law, English, and Economics, 2(01), 21-39. https://doi.org/10.35960/j-lee.v2i01.593

Stirling, B. (2017). TOEFL Strategies: A Complete Guide to the iBT. Nova Press.

Sudarmono, E. (2018). TOEFL Best Preparation. Bintang Wahyu.

Talbert, R. (2017). Flipped Learning: A Guide for Higher Education Faculty. Stylus Publishing, LLC.

Taylor, S. J., Bogdan, R., \& DeVault, M. (2015). Introduction to Qualitative Research Methods: A Guidebook and Resource. John Wiley \& Sons.

Yuliandani, R. P., Ikhsanudin, \& Sumarni. (2014). Analyzing Students' TOEFL Listening Comprehension Test Performance. Jurnal Pendidikan Dan Pembelajaran Khatulistiwa, 3(10), Article 10. https://jurnal.untan.ac.id/index.php/jpdpb/article/view/7275 